\title{
Brachyta (Fasciobrachyta) bureschi (Kantardjieva-Minkova, 1957): a distinct species from North East Bulgaria and South East Romania (North East Balkan Penisula) (Coleoptera Ce- rambycidae Lepturinae Rhagiini)
}

\author{
Pierpaolo Rapuzzi', Cosmin Manci² \& Denis Gradinarov ${ }^{3}$ \\ ${ }^{1}$ via Cialla, 48, 33040 Prepotto, Udine, Italy; e-mail: info@ronchidicialla.it \\ ${ }^{2}$ S.E.O.P.M.M. Oceanic-Club, Constanţa, Romania; e-mail: cosminom@gmail.com \\ ${ }^{3}$ Faculty of Biology, Sofia University "St. Kliment Ohridski", 8 Dragan Tzankov Blvd., 1164 Sofia, Bulgaria; e-mail: \\ dgradinarov@abv.bg
}

\begin{abstract}
Brachyta (Fascibrachyta) bureschi (Kantardjieva-Minkova, 1957) (Coleoptera Cerambycidae Lepturinae Rhagiini) is reevaluated as a distinct species. This taxon was described from Bulgaria (Varna and Kavarna localities) as a form. In Bulgaria, the species was recently found near the second locality of the original description - Vidno Vill., Kavarna municipality. For long time it was recognized as a synonym of $B$. (Fascibrachyta) balcanica (Hampe, 1871).
\end{abstract}

KEY WORDS Bona species; Cerambycidae; Lepturinae; Rhagiini; Bulgaria; Romania.

Received 30.07.2020; accepted 14.11.2020; published online 12.12.2020

\section{INTRODUCTION}

In the last few years several pictures of Brachyta $\mathrm{sp}$. found in Romania appeared on the social media (www.entomologiitaliani.it, facebook) and questions marks were raised regarding the real identity of these specimens.

For Romania, the first mention of Brachyta, as Brachyta balcanica, appear in Fleck from Valul lui Traian (near Constanța) (Fleck, 1905) and later in the monographic work dedicated to Cerambycidae from Sergiu Panin and Nicolae Săvulescu were it is mentioned that all specimens from Romania belong to form bureschi Minkova (Panin \& Săvulescu, 1961). In this book, one specimen from Bulgaria (Cavarna, VI.1925, leg. Lepşi I.) is mentioned as being in Dr. Karl Petri collection. A recent catalogue of Dr. Karl Petri collection, that is stored in Natural History Museum from Sibiu, fails to find this spec- imen in collection (Tăușan \& Bucșa, 2010). Later, Brachyta balcanica was mentioned in the first part of the catalogue of Cerambycidae from "Grigore Antipa" National Museum of Natural History from Bucharest (Serafim, 2005).

In 2018, one of the authors (Cosmin Manci) visited the biotope in Dobrudja region (Cotu Văii (CT), Romania) and collected a small series of specimens. After a study of these specimens, previously identified as Brachyta balcanica (Hampe, 1871), it was clear that they belonged to a distinct species. Checking inside the synonyms (Löbl \& Smetana, 2010, Kantardjieva-Minkova, 1957), we found out that a "form" of Brachyta balcanica was described from north-eastern Bulgaria (Varna and Kavarna localities). Subsequently, a series of specimens were collected from north-eastern Bulgaria (Vidno village, Kavarna municipality), by the last author. Two additional specimens, recently collected from 
Bezhanovo Village (north-eastern Bulgaria near the Romanian border) have also been found in BFUS collection of Sofia University "St. Kliment Ohridski". After the comparison of the newly collected specimens with the original description and the syntype of Evodinus balcanicus bureschi (KantardjievaMinkova, 1957) from the NMNHS collection, we decided that the Romanian and Bulgarian populations from the Black Sea coast in the neighboring territory of the river Danube mouth (steppe vegetation) belong to Brachyta (Fascibrachyta) bureschi (Kantardjieva-Minkova, 1957). The status of this taxon is the object of the present paper.

ACRONYMS. BFUS: Zoological Collection of Sofia University "St. Kliment Ohridski", Faculty of Biology, Sofia, Bulgaria. CAR: Adrian Ruicanescu, Cluj-Napoca (CJ), Romania, private collection. CCM: Cosmin Manci, Iasi (IS), Romania, private collection. CGS: Gianfranco Sama, Cesena (FC), Italy, private collection. CNHM: Croatian Natural History Museum, Zagreb, Croatia. CPR: Pierpaolo Rapuzzi, Cialla di Prepotto (UD), Italy, private collection. MGAB: "Grigore Antipa" National Museum of Natural History, Bucharest, Romania. NMNHS: National Museum of Natural History in Sofia, Sofia, Bulgaria.

\section{RESULTS}

Brachyta (Fasciobrachyta) bureschi (Kantardjieva-Minkova, 1957) bona species (Figs. 1, 2)

Evodinus balcanicus forma bureschi KantardjievaMinkova, 1957, Izvestiya na Zoologicheskiya Institut s Muzei 6: 542. Type loc.: Varna and Kavarna (Bulgaria).

Examined Material (Fig. 18). Brachyta (Faciobrachyta) bureschi (Kantardjieva-Minkova, 1957). Bulgaria: 1 female: Kavarna, 15.IV.[19]09 (Lectotype); 1 male: Stalin [= Varna], Soluk Salaar, 24.V.1953, Karnoschitzky [lgt.]; 2 males: NE Bulgaria, Dobrich prov., Bezhanovo Vill., Kachamaka Place, 70 m., 4343'23"N 28²4'25"'E, 04.IV.2010, D. Kaynarov and S. Beshkov lgt. (BFUS); 7 males and 8 females: NE Bulgaria, Dobrich prov., Kavarna municipality, near Vidno Vill., $80 \mathrm{~m}$., 4334'01,5'N 28²4'21,4'”E, 25.IV.2019, steppe vegetation near farmland, in flowers of Paeonia tenuifolia L., D. Gradinarov and B. Zlatkov lgt. (BFUS). 19 specimens.
The last locality (Vidno Vill.) is located less than $10 \mathrm{~km}$ from the type locality and appears to represent the same population of the species.

Romania: 1 female: Agigea, 9.VI.1958, F. Cârdei lgt. (MGAB); 1 male: Murfatlar, 17.V.1962, N. Săvulescu lgt. (MGAB); 2 females: Hagieni, 29.V.1963, N. Săvulescu lgt. (MGAB); 3 females: Hagieni, 21.V.1965, N. Săvulescu lgt. (MGAB); 1 male and 10 females: Hagieni, 29.IV.1991, N. Săvulescu lgt. (MGAB); 6 males and 7 females: Hagieni, 30.IV.1991, N. Săvulescu lgt. (MGAB); 2 males and 11 females: Hagieni, 1.V.1991, N. Săvulescu lgt. (MGAB); 7 males and 24 females: Cotu Văii, 19.IV.2018, C.-R. Stanciu lgt. (MGAB); 2 females: Hagieni, 6.V.1993, E. Nitu lgt. (CAR); 2 males and 1 female: Cotu Văii, 23.IV.2019, R. Georgescu lgt. (CAR); 10 males and 7 females: Cotu Văii, 19.IV.2018, C.-R. Stanciu lgt. (CCM); 3 females: Cotu Văii, 23.IV.2018, C-O. Manci lgt. (CCM); 3 males: Hagieni, 24.IV.2019, C-O. Manci lgt. (CCM); 16 males and 24 females: Cotu Văii, 25.IV.2019, C-O. Manci lgt. (CCM); 3 males and 1 female: Coroana, 26.IV.2019, C-O. Manci lgt. (CCM); 3 males and 2 females: Cotu Văii, 27.IV.2019, C-O. Manci lgt. (CCM); 3 males and 12 females: Coroana, 27.IV.2020, C.-R. Stanciu lgt. (CCM); 2 males and 1 female: Hagieni, 28.IV.2020, C.-R. Stanciu lgt. (CCM); 2 females: Coroana, 28.IV.2020, C.-R. Stanciu lgt. (CCM). 172 specimens.

Brachyta (Fasciobrachyta) balcanica (Hampe, 1871). Croatia: 1 male: Varaždin, Lepoglava, [1]933 (CNHM). 1 specimen. Serbia: 1 male and 1 female: Devojač bunar, Deliblato Peščara, 24.IV.2004, N. Ilić lgt.(CPR). 2 specimens. Albania: 1 female: Kula Ljums, 18-26.V.[19]18 (CGS). (1 specimen). Bulgaria: 1 male: Slivno, 1902 (CGS); 2 females: StaraZagora, Col N. Nedelkov (NMNHS); 2 males: Burgas, P. Tschorbadjieff [lgt.] (NMNHS); 1 male: Haskovo, V. 1897, Col. D. Ioakimov (NMNHS); 2 females: Burgas, IV.[1]906, Col N. Nedelkov (NMNHS); 1 male: Sliven, Kushbunar [Place], 27.V.[1]923, P. Tschorbadjieff [lgt.] (NMNHS); 1 male: Sakar P1. [=Sakar Mts.], 26.V.1951, Dr. N. Atanassov and V. Petrov (NMNHS); 1 female: Sarnena Gora Mts., Beter Peak, 809 m., 42³0’41,2'”N 2537'46,4' E, 28.V.2018, mixed deciduous forest, D. Georgiev lgt. (BFUS); 1 male: W Rhodopes Mts., $2 \mathrm{~km}$ SW Asenovgrad, 780 m., 41 $59^{\prime} 46,7^{\prime \prime} \mathrm{N}$ $24^{\circ} 50$ '44,5”'E, 26.IV.2017, mixed deciduous forest, 


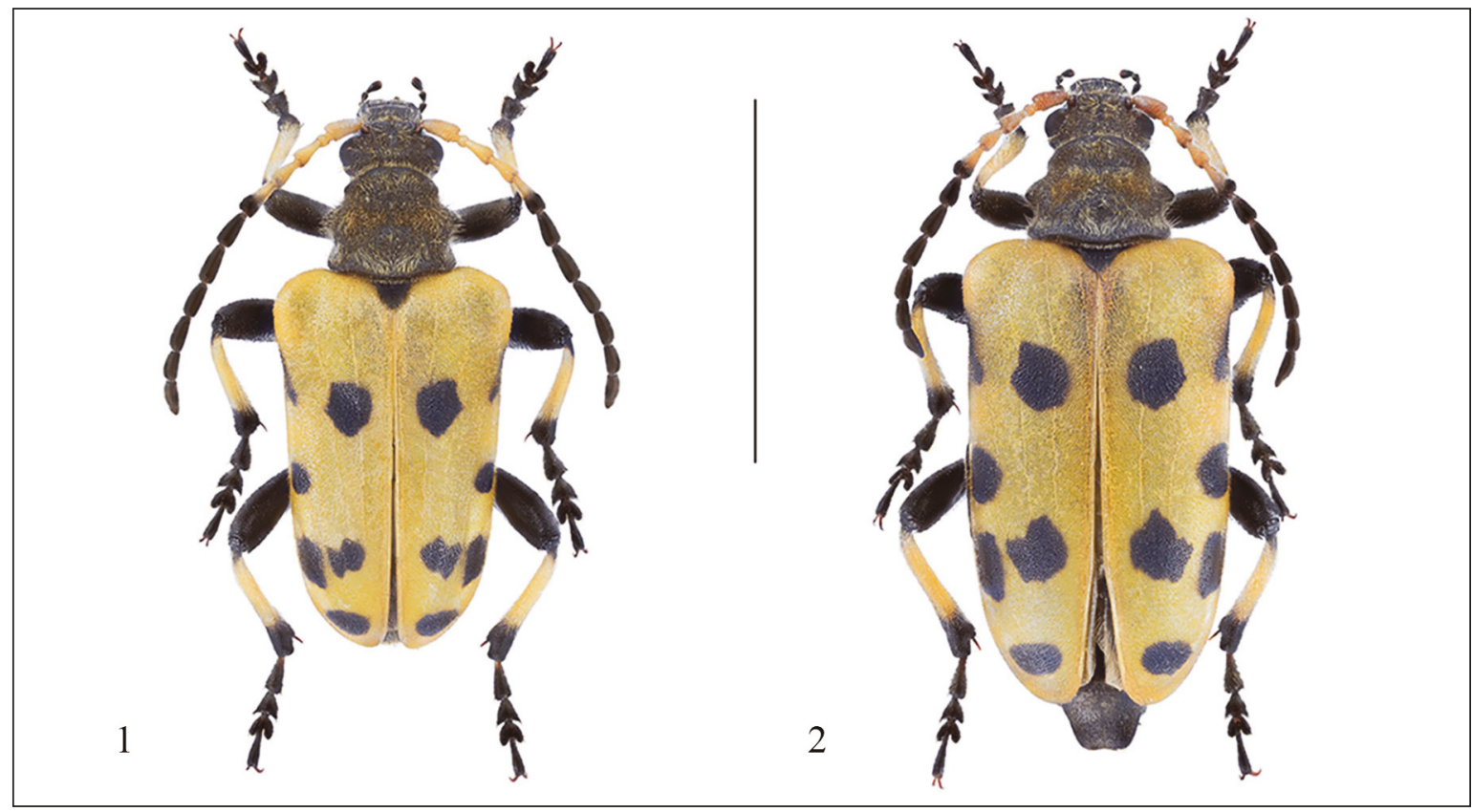

Figures 1, 2. Brachyta bureschi habitus: male (Fig. 1) and female (Fig. 2). Scale bar: $10 \mathrm{~mm}$.

O. Sivilov and B. Zlatkov lgt. (BFUS); 5 males and 7 females: W Rhodopes Mts., $2 \mathrm{~km} \mathrm{SW}$ Asenovgrad, 780 m., 41 ${ }^{\circ} 59^{\prime} 46,7^{\prime}$ N 2450'44,5'”, 26.IV.2019, mixed deciduous forest, on leaves of Paeonia peregrina Mill., D. Gradinarov and B. Zlatkov lgt. (BFUS). 24 specimens. Greece: 1 male: Thrace: Evros, Ft. De Pesani, 30.IV.2004 (CPR); 61 males and 21 females: Thrace: Evros, Loutros Dadia, 29 Km S Dadia, 25-27.IV.2007 (CPR); 1 male: Thrace, Sapka Mts., Nea Santa env., 4107'29,06”N 2553'48,60'E, 30.IV.2014, D. Vit lgt. (CPR); 1 male and 1 female: Thrace: Panagiá, Pangaion Mt., 24.V.2016. I. Martinu lgt. (CPR); 3 males and 8 females: Thrace: Panagiá, Pangaion Mt., 16.V.2018, 970 m., I. and R. Martinu lgt. (CPR); 1 female: Thrace, Rodopi Mts., Nea Santa vill., 760 m., 78.V.2014. S. Dementyev lgt. (CPR); 1 male: Thrace: Panagiá, Pangaion Mt., 24.V.2016. I. Martinu lgt. (CCM); 1 female: Thrace: Panagiá, Pangaion Mt., 16.V.2018, 970 m., I. and R. Martinu lgt. (CCM). (100 specimens). Turkey: 1 female: Gümüshane prov., Gümüshane, VI.1972, C. Holzschuh lgt. (CPR); 1 female: Giresun prov., Soğanli, 2000 m., 25.VI.1992, A. Del Fabbro lgt. (CPR); 1 male and 1 female: Giresun prov., Soğanli, $2000 \mathrm{~m}$., 25.VI.1992, G. Proscia lgt. (CPR); 1 female: Giresun prov., Soğanli, 1800 m., 25.VI.1987 (CPR); 3 males and 1 female: Erzincan prov., Caglayan, Girlevik Mts., 2100 m., 12-19.VI.1993, P. Kabátek lgt. (CPR); 1 male: Erzincan prov., $20 \mathrm{Km} \mathrm{E} \mathrm{Erzin-}$ can, Çakrilar, Munzur Dağ., 1800 m., 39³6'N 39²3’E, 15-16.VI.2005, T Rybárik lgt. (CPR); 2 males and 2 females: Sivas prov., North of Zara, Kurbagalibeli Geç., 1800 m., 4.VI.1998, S. Kadlec lgt. (CPR); 1 female: Sivas prov., North of Zara, Kurbagalibeli Geç., 1800 m., 3.VI.1998, M. Rejzek lgt. (CPR); 2 males and 2 fermales: Sivas prov., env. Zara, 3-5.VI.2003, D. Farbiak lgt. (CPR). 18 specimens.

Brachyta (Fasciobrachyta) petriccionei Rapuzzi, Bologna et Poloni, 2019. Italy: 1 female: Abruzzo, Monte Morrone (PE), 1500 m, 23.V.2019, R. Poloni, P. Rapuzzi, M.A. Bologna, M. Carafa and B. Petriccione lgt. (CPR); 1 male: Abruzzo, Monte Morrone (PE), 1500 m, 29.V.2019, M. Carafa lgt., 2 exx (CPR).

ORIGINAL DESCRIPTION (in Bulgarian). “Дв $\widehat{\jmath} u$ ф екземпляри, уловени в гр. Варна по ияветовете на божури на 11. V. 1952 г. От Н. Карножицки, и един ㅇ екземпляр от гр. Каварна от 15. IV. 1909 г., намерен в сбирката на А. Маркович, притежават следните белези:

Тялото е черно, при + + иироко и масивно. Елитрите бледожълти, до по-тьмни. Първите 
5 членчета на антените (с изключение на върха на 5-то членче) са жълти, останалите членчета са черни. Краката са черни, с изключение на пищялите без върха им, които са жълти. Елитрите бледожълти, еднообразно и гъсто пунктирани, покрити с ниско лежащи жълтеникави космици. Всяко крило носи по 6 черни петна: три са разположени успоредно и близо до средния шев на крилото и три странични -близо до страничния ръб на крилото.
Тези до средния шев са: I-то закръглено пред средата на крилото, II-то неправилно четириъгълно - зад средата на крилото, и IIIто кръгло - близо до върха на крилото. От страничните три черни петна двете крайни са по-големи и неправилно удължени, средното е по-малко и закръглено. Средното петно от вьтрешната редииа и долното крайно от вьншната редица се разширяват и допират едно до друго. Големина на тялото при ठิ $\widehat{\sigma}-16$ мм, при $\odot$ - 17 мм.

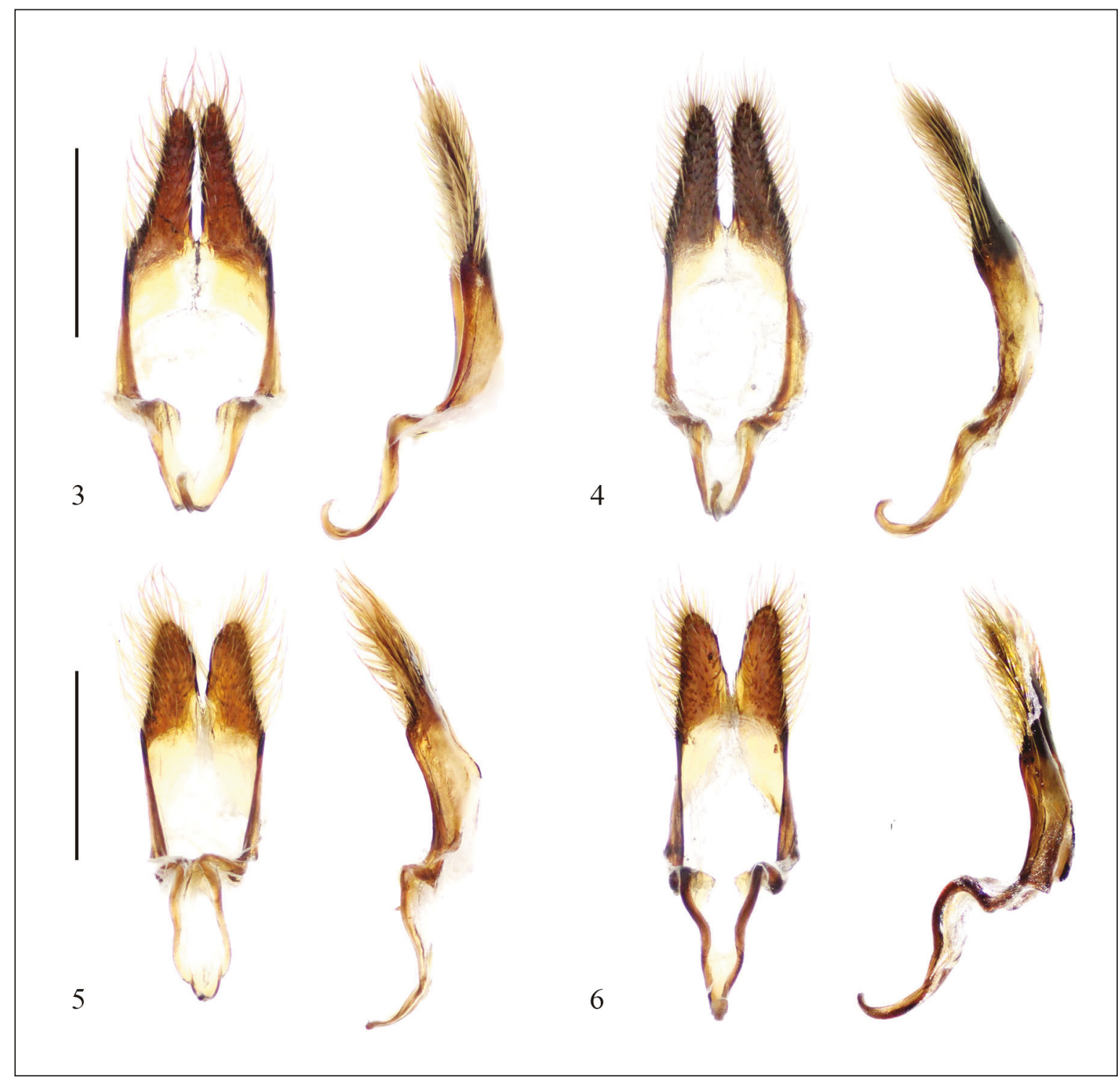

Figures 3-6. Tegmen of Brachyta bureschi and B. balcanica (ventral and lateral view). Fig. 3: Brachyta bureschi: Varna, Karnoschitzky. Fig. 4: Brachyta bureschi: Vidno locality. Fig. 5: Brachyta balcanica: Burgas, P. Tschorbadjieff. Fig. 6: Brachyta balcanica: Asenovgrad locality. Scale bar: $1 \mathrm{~mm}$. 
Brachyta (Fasciobrachyta) bureschi: a distinct species from NE Bulgaria and SE Romania (Coleoptera Cerambycidae) 907

Дължина на елитрите при $\widehat{\partial} \widehat{\partial}-11 \cdot 5$ мм.

Дължсина на елитрите при ㅇ ㅇ - 12·8-13 мм.

Находища: гр. Варна - 2 екземпляра ( $\widehat{\jmath}$ и $९)$ ); гр. Каварна - 1 екземпляр () - фиг. 1 и 2".

[Translation in English: Two (o and +) specimens, found on peony flowers in the town of Varna by N. Karnoschitzky on 11. V. 1952; one o specimen from Kavarna, 15. IV. 1909, from the collection of A. Markovich, with the following characters:

Body black, in 우 아 broad and robust. Elytra pale yellow to darker. the first five antennal seg- ments (except for the apex of the 5-th segment) yellow, the rest are black. Legs black, except for tibiae, which are yellow with the exception of the apex. Elytra pale yellow, uniformly and densely punctured, covered with oblique yellowish hairs. Each wing [elytra] with 6 black spots: 3 parallel and close to the wing [elytral] suture and three lateral, close to lateral edge of the wing [elytra].

These [close] to the suture are: the first rounded - before the middle of the wing [elytra], the second irregularly quadrangular - behind the middle of the
7

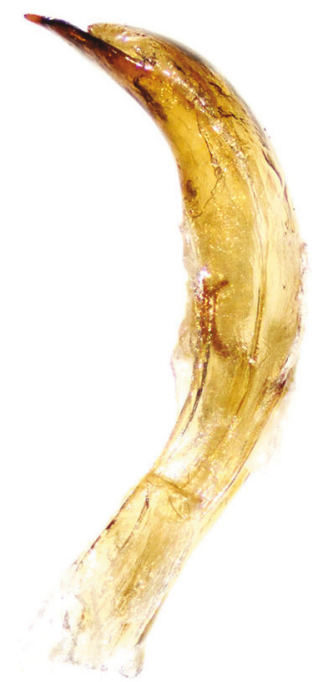

9

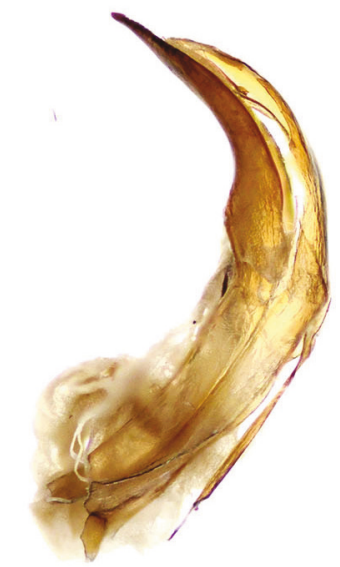

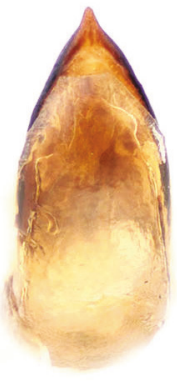

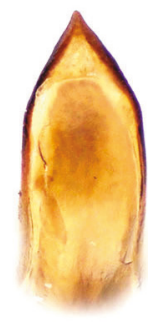

8
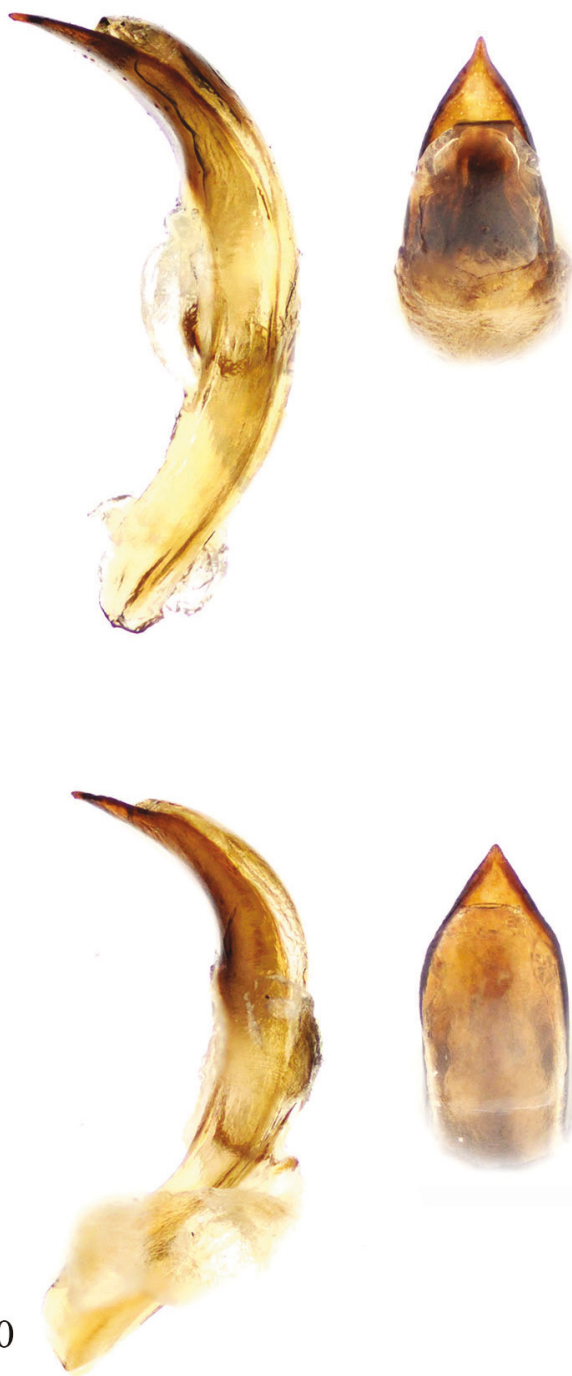

Figures 7-10. Median lobe (penis) of Brachyta bureschi and B. balcanica (lateral view and apex). Fig. 7: Brachyta bureschi: Varna, Karnoschitzky. Fig. 8: Brachyta bureschi: Vidno locality. Fig. 9: Brachyta balcanica: Burgas, P. Tschorbadjieff. Fig. 9: Brachyta balcanica: Asenovgrad locality. Scale bar: $1 \mathrm{~mm}$. 
wing [elytra] and the third - close to the apex of the wing [elytra]. Of the three black lateral spots the outer two are larger and irregularly elongated, the middle one is smaller and rounded. The middle spot of the inner line and the lower external spot of the lateral line are expanded and contiguous. Body length in $\widehat{\partial} \widehat{O}-16 \mathrm{~mm}$, in 9 ㅇ $-17 \mathrm{~mm}$.

Elytral length in $\widehat{0} \widehat{0}-11.5 \mathrm{~mm}$.

Elytral length in 9 - $-12.8-13 \mathrm{~mm}$.

Localities: Varna - 2 specimens ( $\widehat{\sigma}$ and + ); Kavarna -1 specimen ( $(+)$.

VARIABILITY. The black drawing on the elytra is very variable. In all the known species of this group the pattern is very stable and only small variations are known (spots more or less large). In the series of $B$. bureschi that we studied the spots are jointed in different ways, sometimes the elytra being totally black. An interesting variation is that in some specimens all yellow foreground coloration is replaced by a brownish hue where black spots are barely visible. Variations is present in both sexes, but males apparently have a more stable pattern compared with females that are much more variable (Figs. 16, 17).

Biology. In Romania, adult specimens are known to fly from April to May, or even June (Agigea, 9.VI.1958). We have found specimens only in the second half of April and always on Paeonia tenuifolia, in flowers or on the plants where they appear to rest the until second part of the day. We have observed that adults rarely fly and

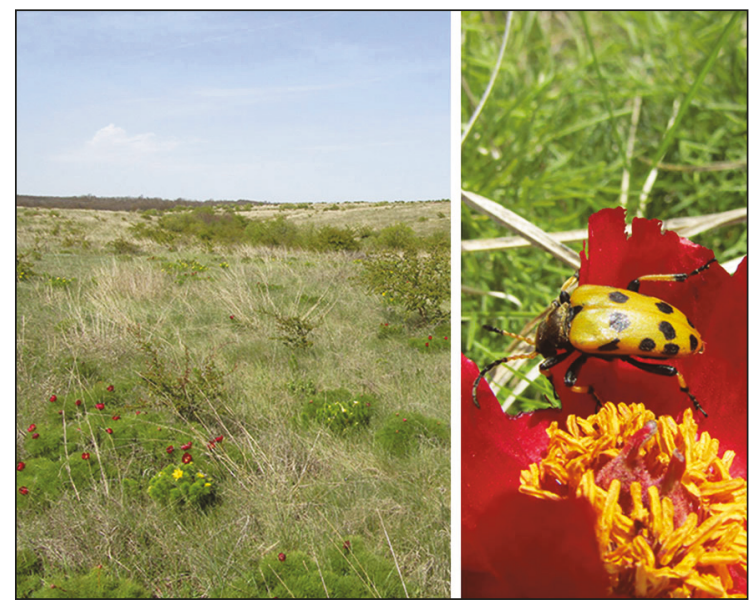

Figure 11. Habitat and host plant (Paeonia tenuifolia L.) of Brachyta bureschi (Bulgaria, Vidno locality). that only in the second part of the day. Adults were observed eating petals or anthers of Paeonia tenuifolia. From our observations, copulation takes place also only inside flowers. Rarely, we have seen females on basal part of the plant suspecting that before was on the ground laying eggs. In March 2019, there has been an attempt to search for larva but it had no success. In future, it will be needed to mark the host plant were to try and dig later (end of autumn or very early in spring) for larvae and/or pupae.

In Bulgaria, adults of Brachyta bureschi have been collected from the beginning of April to the second half of May. Within the present study, individuals of the species were observed feeding on petals of Paeonia tenuifolia L.

The habitat type of both recent species localities in Bulgaria and Romania belongs to WesternPontic petrophytic steppes (Ponto-Sarmatic steppes). In Bulgaria, the remains of these habitats are only preserved in the northeastern parts of the country and are heavily affected by human activity (Tzonev et al., 2011), which may explain the rarity of this species. In Romania, even if the habitat is known to be a big part of Dobrodja, Brachyta is known today only from few locations close to the Bulgarian border. We tried to look for the species also in localities in which it was mentioned historically: Murfatlar, Agigea, Valul lui Traian but without success even if in some of this localities the host plant still exist (Fleck, 1905; Panin \& Savulescu, 1961).

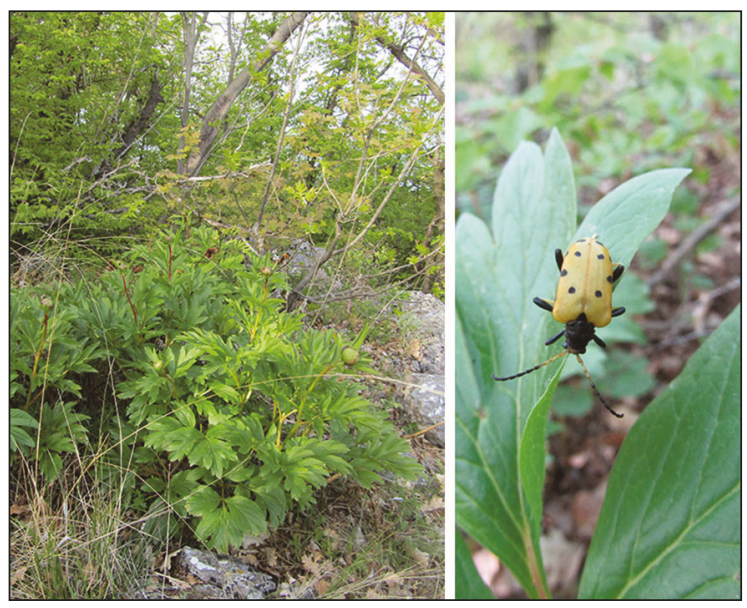

Figure 12. Habitat and host plant (Paeonia peregrina Mill.) of Brachyta balcanica (Bulgaria, Asenovgrad locality). 
REMARKS. In the historical part of the NMNHS collection eleven specimens of $B$. balcanica are preserved. Of these, only two correspond to the type locality of B. balcanica f. bureschi (one male and one female).

The male specimen is labeled "STALIN [= Varna] / 24. V. 1953 [?] / KARNOSCHITZKY “/ [backside of the label] Soluk Salaar [Place]// gender symbol.

The locality and the collector (Karnoschitzky = Карножицки) are the same as in the description (Kantardjieva-Minkova, 1957: 542), but the date of collection does not match (11. V. 1952 in the original description). This specimen is not listed either among the types of bureshi or in the list of specimens, identified as Evodinus balcanicus Hampe (as said abowe, in Bulgarian).

The female fits well with KantardjievaMinkova's description. The labels are as follows: 15 . IV. [19]09/ Yala Yuch orman [currently Gorichane Vill.]/ Kavarna [in Bulgarian] // Evodinus balcanicus Hampe // gender symbol // Evodinus balcanicus bureschi - Mink. In the historical collection of the NMNHS, this is the only specimen pinned directly to the label with the name "Evodinus balcanicus bureschi - Mink.". The collection date and the main toponym are the same of the third specimen (the second female) in the description paper (in Bulgarian; Kantardjieva-Minkova, 1957: 542). Kantardjieva-Minkova may have not been able to identify the first toponym on the label and therefore did not include it in the description.
For this reason we fixed the female specimen as Lectotype and provided it with a red label with the indication: Lectotype/Evodinus balcanicus $f$. bureschi/Kantardjieva-Minkova 1957/des. P. Rapuzzi, C. Manci and D. Gradinarov, 2019.

According to the ICZN art.45.6.4: "It is subspecific if first published before 1961 and its author expressly used one of the terms "variety" or "form" (including use of the terms "var.", "forma", "v." and "f."), unless its author also expressly gave it infrasubspecific rank, or the content of the work unambiguously reveals that the name was proposed for an infrasubspecific entity, in which case it is infrasubspecific". Since it was described as "forma" before 1961 the name should be regarded as available and for this reason it must be accepted as valid.

\section{DISCUSSION}

Brachyta bureschi belongs to Brachyta balcanica group of species. It differs from $B$. balcanica due to the particular composition of the elytral drawing made by larger black points. The closest species is B. (Fasciobrachyta) petriccionei (Figs. 13-15) recently described from Central Italy (Abruzzo region) that can be distinguished by the particular elytral drawing. It is easy to distinguish from the Italian species due to the sparser silver pubescence on the pronotum, denser and golden in $B$. petriccionei. The lateral tooth on pronotum is smaller and shorter and also the disk of pronotum

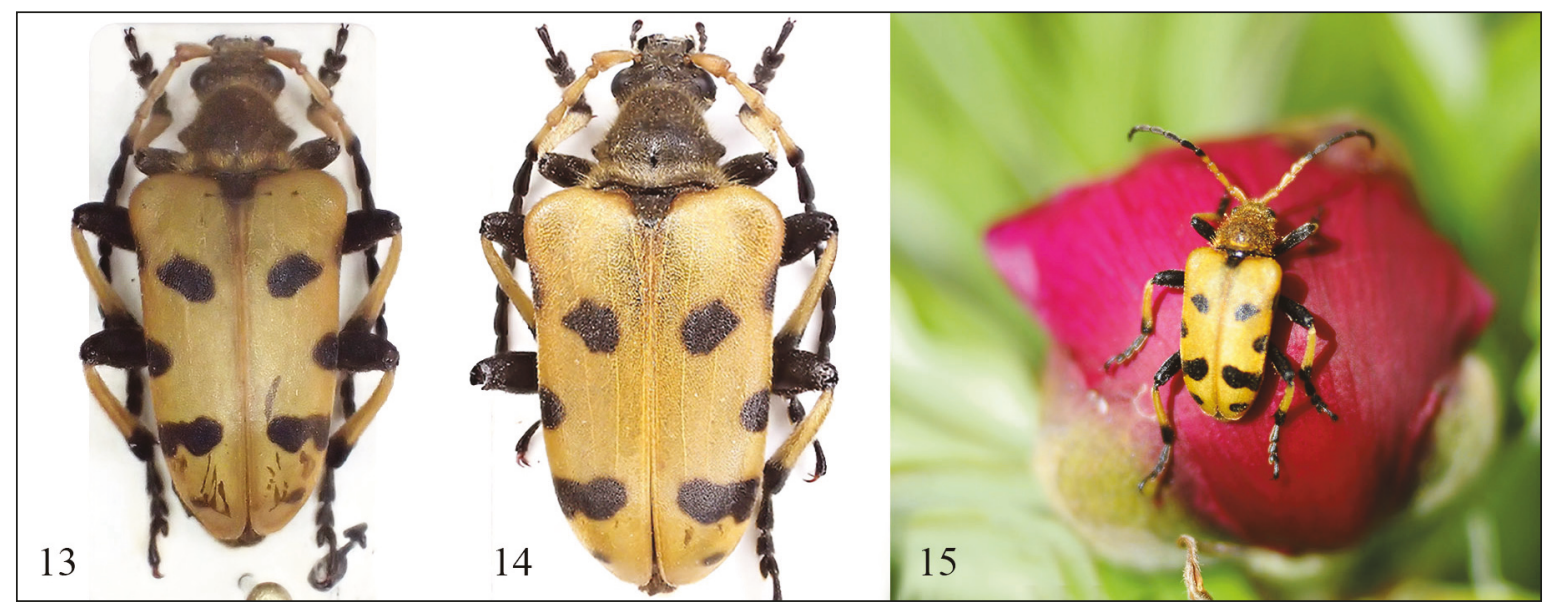

Figure 13. Brachyta petriccionei (Italy, Monte Morrone) Holotypus female. Figure 14. Idem, male. Figure 15. Habitat and host plant (Paeonia officinalis L.) of Brachyta petriccionei (Italy, Monte Morrone) (photo Marco Carafa). 


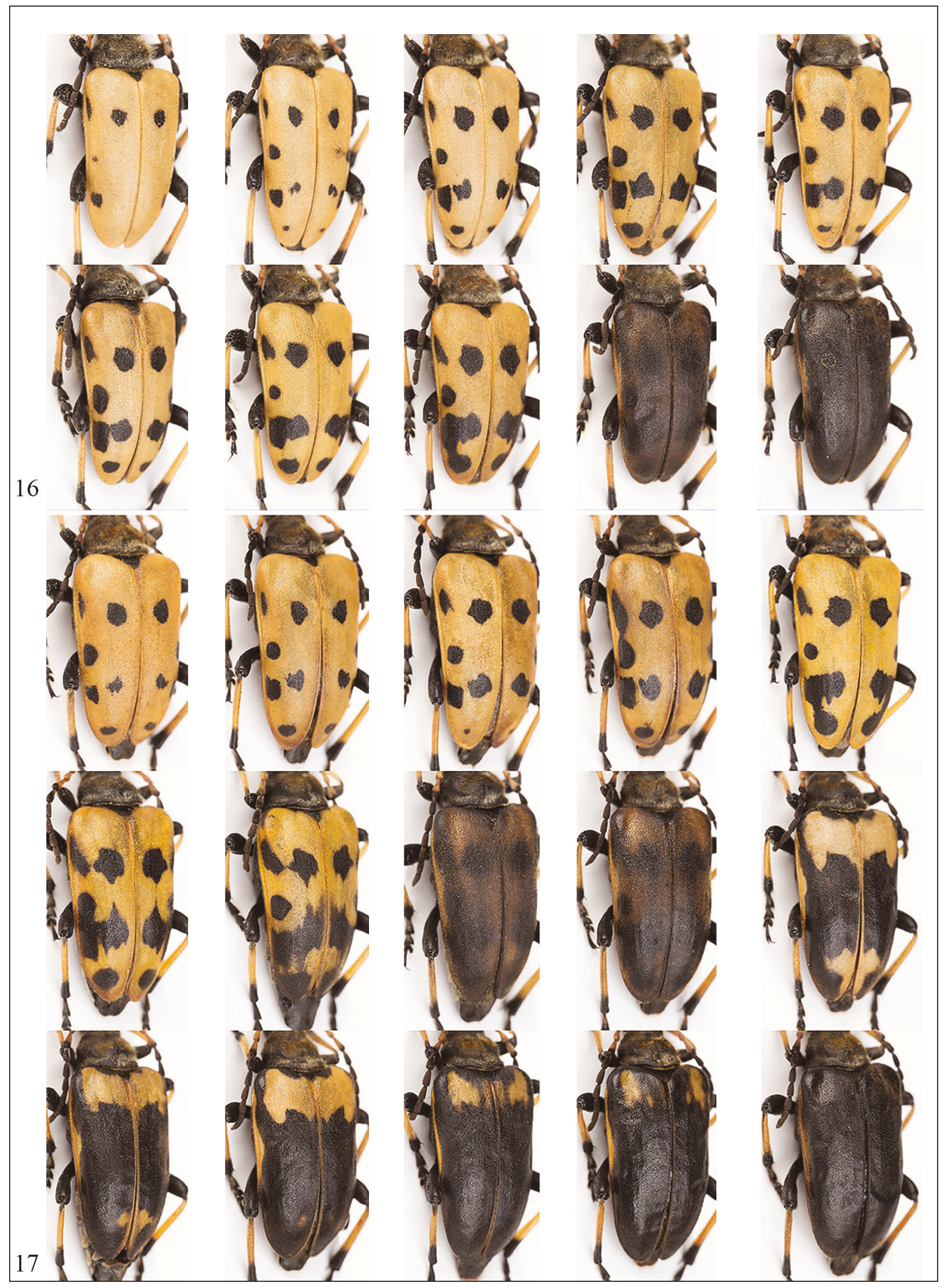

Figure 16. Variability in males of Brachyta. bureschi (Romania) (not on scale). Figure 17. Variability in females of Brachyta. bureschi (Romania) (not on scale) 


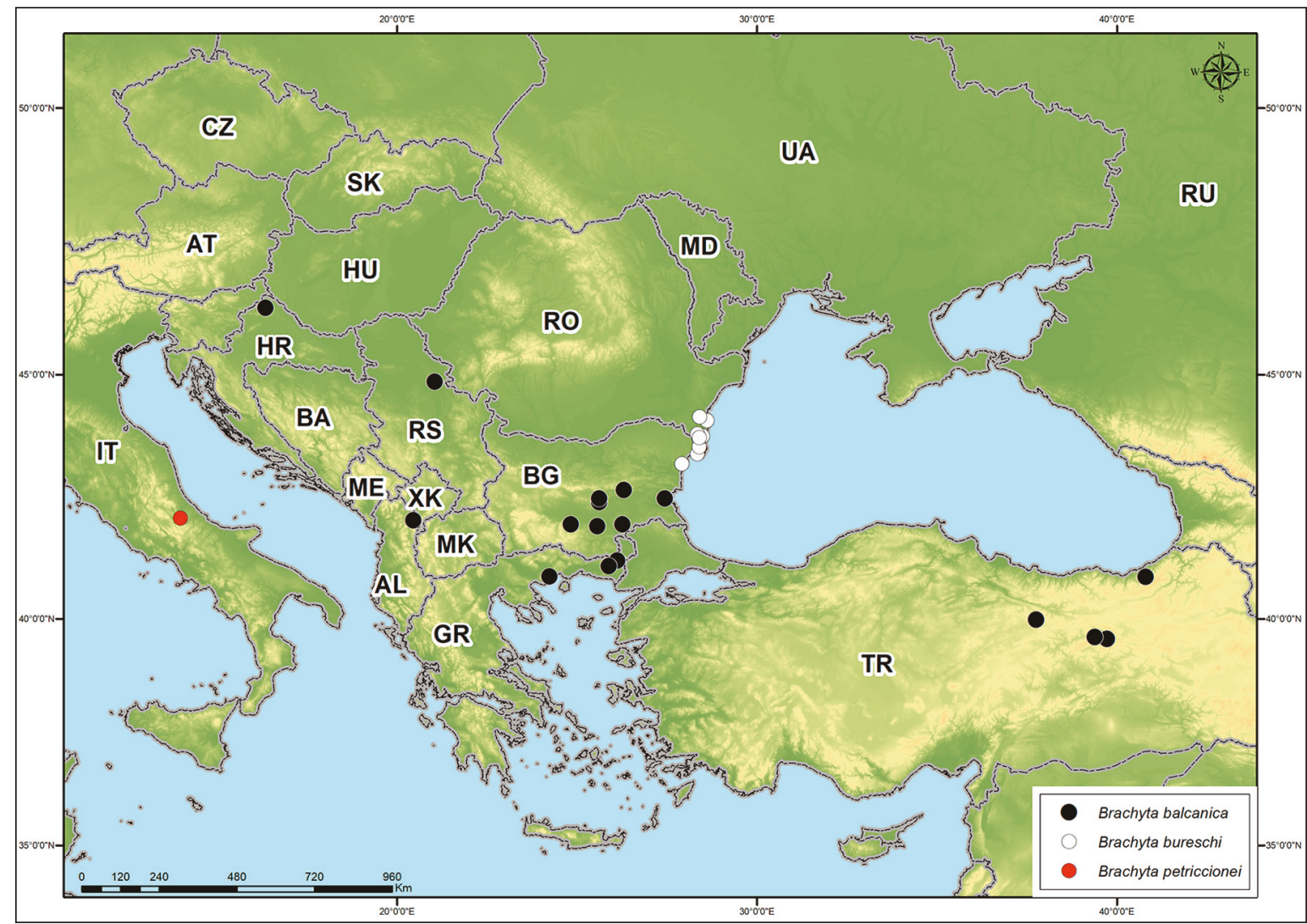

Figure 18. Distribution map of Brachyta balcanica, B. bureschi and B. petriccionei (based on examined specimens).

is flatter than in B. petriccionei. The disk of elytra is flatter and the light ground color is lighter in $B$. bureschi. The two pre-apical points are usually jointed in an incomplete band, interrupted close to the suture; this transversal band is also similar in $B$. (Fasciobrachyta) caucasica (Rost, 1892) but in the Balkan species it is curved towards the base of the elytra instead of horizontal and bent backwards at the outer edge. The ground color is a paler yellow than in all the other species known from this group. The pubescence on the pronotum and on the head in specimens of $B$. bureschi from Bulgaria and Romania, the hairs on the head are clearly lighter than hairs on the pronotum, nearly yellowish is made by short and long thin silvery hairs instead of black as in B. balcanica; these hairs are evidently denser and longer than in B. balcanica. The elytral punctuation is denser and deeper. The sculpture on the pronotum and on the head is stronger and made by points of different size, more regular in size in B. balcanica.

A comparison of the male genitals of several in- dividuals of $B$. balcanica and B. bureschi from Bulgaria was also performed. B. bureschi obviously differs from B. balcanica by the slender and longer parameres, by the general shape of the tegmen (Figs. 3-6) and by the distinctly pointed apex or the penis (Figs. 7-10). Male genitalia of B. bureschi from Romania is similar with the one from Bulgarian specimens.

Apart from the morphological differences, the species appears to have a different host plant. In Bulgaria, B. bureschi was observed feeding on Paeonia tenuifolia L. (Vidno locality) (Fig. 11), while B. balcanica on P. peregrina Mill. (Asenovgrad locality) (Fig. 12). Brachyta petriccionei was collected on the leaves of Paeonia officinalis L. (very likely its host) (Fig. 15). In Romania, from our knowledge only $B$. bureschi exist and even in a locality, Coroana, where both species of Paeonia (tenuifolia and peregrina) co-occur, the species was found to be only on Paeonia tenuifolia and no specimens being found on Paeonia peregrina. 


\section{ACKNOWLEDGEMENTS}

We are grateful to our friend Dr. Vlatka Micetic Stankovic, curator of the Entomological collections preserved in the Croatian National History Museum (Zagreb, Croatia) for the opportunity to study the $\mathrm{Ce}$ rambycidae preserved in their collections, Dr. Borislav Guéorguiev (National Museum of Natural History, Sofia, Bulgaria) for providing access to Coleoptera collection of NMNHS and to Dr. Melania Stan from Grigore Antipa National Museum of Natural Sciences (Bucharest, Romania) for providing access to Coleoptera collection of MGAB. We are grateful also to Dr. Ognyan Sivilov (Sofia University, Bulgaria), Dr. Dilyan Georgiev (Plovdiv University, Bulgaria), MSc Dimitar Kaynarov and Dr. Adrian Ruicănescu for kindly providing specimens of Brachyta spp. Many thanks to Dr. Marco Carafa, zoologist, Parco Nazionale della Majella (Abruzzo, Italy), for the picture of Brachyta petriccionei in nature. The second author is grateful to Dr. CătălinRăzvan Stanciu (Constanta, Romania) for his help in assisting with collecting a series of specimens in 2018 and 2020 and to Dr. Tiberius Sahlean for ArcGIS work for the map. The last author is sincerely grateful to Dr. Boyan Zlatkov (Institute of Biodiversity and Ecosystem Research, Sofia, Bulgaria) for his invaluable assistance in collecting the new material from Bulgaria. We also want to thank Dr. Maurizio Pavesi (Museo Civico di Storia Naturale, Milano, Italy) for the suggestion and help with ICZN. A special thanks to our friend Gianfranco Sama (Cesena, Italy) for his support and constant help.

\section{REFERENCES}

Danilevsky M.L., 2014. Longicorn Beetles (Coleoptera,
Cerambycidae) of Russia and adjacent countries. Part 1. M.: HSC. 518 pp. (in Russian).

Fleck E., 1905. Die Coleopteren Rumaniens (part 5). Bulletin de la Societe de Sciences, Bucarest - Roumania, 14: 490-570

Kantardjieva-Minkova S., 1957. Nowi I redki vidove ot semeystvo Cerambycidae v Belgaria. Izvestiya na Zoologicheskiya Institut s Muzei, 6: 539-551.

International Commission on Zoological Nomenclature, 1999. International Code of Zoological Nomenclature, 4 th ed., $306 \mathrm{pp}$.

Löbl I. \& Smetana A., 2010. Catalogue of Paleartic Coleoptera. 6. Chrysomeloidea. Apollo Books, Stenstrup, $924 \mathrm{pp}$.

Panin S. \& Săvulescu N., 1961. Coleoptera: Cerambycidae. In: Fauna României. Edit. Academiei Române, 10: $1-523$.

Rapuzzi P., Bologna M.A. \& Poloni R., 2019. Brachyta (Fasciobrachyta) petriccionei, a new Longhorn beetle species from Central Italy. Fragmenta Entomologica, 51: 97-101. https://doi.org/10.481/fe.2019.338

Serafim R., 2006. The Catalogue of the Palaearctic species of Lepturinae (Coleoptera: Cerambycidae) from the patrimony of "Grigore Antipa" National Museum of Natural History (Bucharest). (Part II). Travaux du Muséum National d'Histoire Naturelle "Grigore Antipa", 49: 203-238.

Tăușan I. \& Bucșa C., 2010. Palaearctic longhorn beetles (Coleoptera: Cerambycidae) from "Dr. Karl Petri" collection of the Natural History Museum of Sibiu (Romania). Part I: Lepturinae subfamily. Travaux du Museum National d'Histoire Naturelle "Grigore Antipa", 53: 223-233

Tzonev R., Roussakova V. \& Dimitrov M., 2011. Western-Pontic petrophytic steppes. In: Biserkov V. et al. (Eds.), Red Data Book of the Republic of Bulgaria. Volume 3 - Natural habitats. Bulgarian Academy of Sciences \& Ministry of Environment and Water. Available at: http://www.e-ecodb.bas.bg/rdb/en/vol3/ 08E1.html (Accessed on 16 April 2020). 